\title{
Stereoselective Synthesis of Optically Active Dictyopterenes A and B and Their Geometrical Isomers
}

\author{
Tadahiko Kajiwara, Toshihiro Nakatomi, Yasushi Sasaki \\ and Akikazu HATANAKA \\ Department of Agricultural Chemistry, University of Yamaguchi, \\ Yamaguchi 753, Japan \\ Received March 12, 1980
}

\begin{abstract}
Optically active dictyopterenes A and B and their geometrical isomers were stereoselectively synthesized by condensation of acrolein with carboethoxymethyl dimethylsulfonium bromide and by the Wittig reaction between ( + )-2-vinylcyclopropylearbaldehyde, which was derived from partially resolved $(+)-(1 S, 2 R)$-2-vinylcyclopropanecarboxylic acid, and phosphonium salts in liquid-solid two-phase systems using crown ethers.
\end{abstract}

Dictyopterene $\mathrm{A},(+)-(R, R)-1-[(E)$-hex-1'enyl]-2-vinylcyclopropane $[(+)-1 \mathbf{a}]$, and dictyopterene $\mathrm{B},(-)-(R, R)-1-\left[(E),(Z)\right.$-hexa-1', $3^{\prime}$ dienyl]-2-vinylcyclopropane $[(-)-2 a],{ }^{1-3)}$ dictyopterene $\mathrm{C}^{\prime},(R)-(-)$-6-butylcyclohepta-1,4diene $[(-)-3],{ }^{2,3)}$ and dictyopterene $\mathrm{D}^{\prime}$ (ectocarpene), $\quad(S)-(+)-6-[(Z)$-but-1'-enyl]-cyclohepta-1,4-diene $[(+)-4], "$ have been isolated from the essential oils of brown Hawaiian sea-weeds, Dictyopteris plagiogramma (Montagne) VICKERS and D. australis SONDER.

The $\mathrm{C}_{11}$-unsaturated hydrocarbons $[(+)-1 \mathbf{a}$ and (-)-2a] are odoriferous constituents responsible for the "ocean smell" and (+)-4 is the male-attracting substance of a brown alga. ${ }^{4)}$ The thermal rearrangement of $(+)-\mathbf{1 a}$ and (-)-2a to (+)-3 and (-)-4, respectively, stimulated syntheses of $1 a^{, 5-10}, \mathbf{2}^{11 !}$ and the related compounds in racemic forms.

However, optically active dictyopterenes have not been synthesized so far. This paper describes stereoselective synthesis of $(+)$ dictyopterene $\mathrm{A}[(+)-\mathbf{1 a}],(-)$-dictyopterene $\mathrm{B}$ [(-)-2a], and their geometrical isomers: (-)$(R, R)$ - 1 - [(Z)-hex-1'-enyl]-2 -vinylcyclopropane $(-)-1 \mathrm{~b}$ and $(-)-(R, R)-1-\left[(Z),(Z)\right.$-hexa-1', $3^{\prime}-$ dienyl]-2-vinylcyclopropane (-)-2b, as shown in the Fig. 1.

Preparation of ethyl trans*-2-formylcyclopropanecarboxylate (5a)

The key synthon, ethyl trans-2-formylcyclo- propanecarboxylate (5a) was prepared by condensation of acrolein with the ylid of carboethoxymethyl dimethylsulfonium bromide (the method of Payne) ${ }^{12}$ or the sulfonium salt (a modified method) ${ }^{13 !}$ in liquid-solid twophase systems using crown ethers.

i) Payne's method. In order to find the best reaction conditions for the trans-cyclopropane formation, condensations of the stabilized sulfonium ylid with the unsaturated aldehyde in various aprotic solvents were investigated (Table I). Fortunately, the small amount of cis-contaminant (5b) was removed by $\mathrm{NaBH}_{4}$ reduction followed by distillation in vacuo. The carbinol (6) thus obtained, without further purification, was oxidized with pyridinium chlorochromate ${ }^{14}$ ) to give a sterically pure trans-isomer (5a).

ii) Modified method. To a mixture of the sulfonium halide, bases and crown ether in THF and/or dichloromethane, was added the unsaturated aldehyde at room temperature. After stirring for a while, 5a was obtained in $60 \sim 70 \%$ yields (Table II). Table II indicates that the trans-isomer (5a) is selectively produced in THF using 18-crown-6-potassium carbonate. In the absence of crown ethers, little or no product formation was observed. A major advantage of this procedure is the simplicity of the one step reaction to afford

* cis,trans-Notation for stereochemical structure of the cyclopropane ring. 

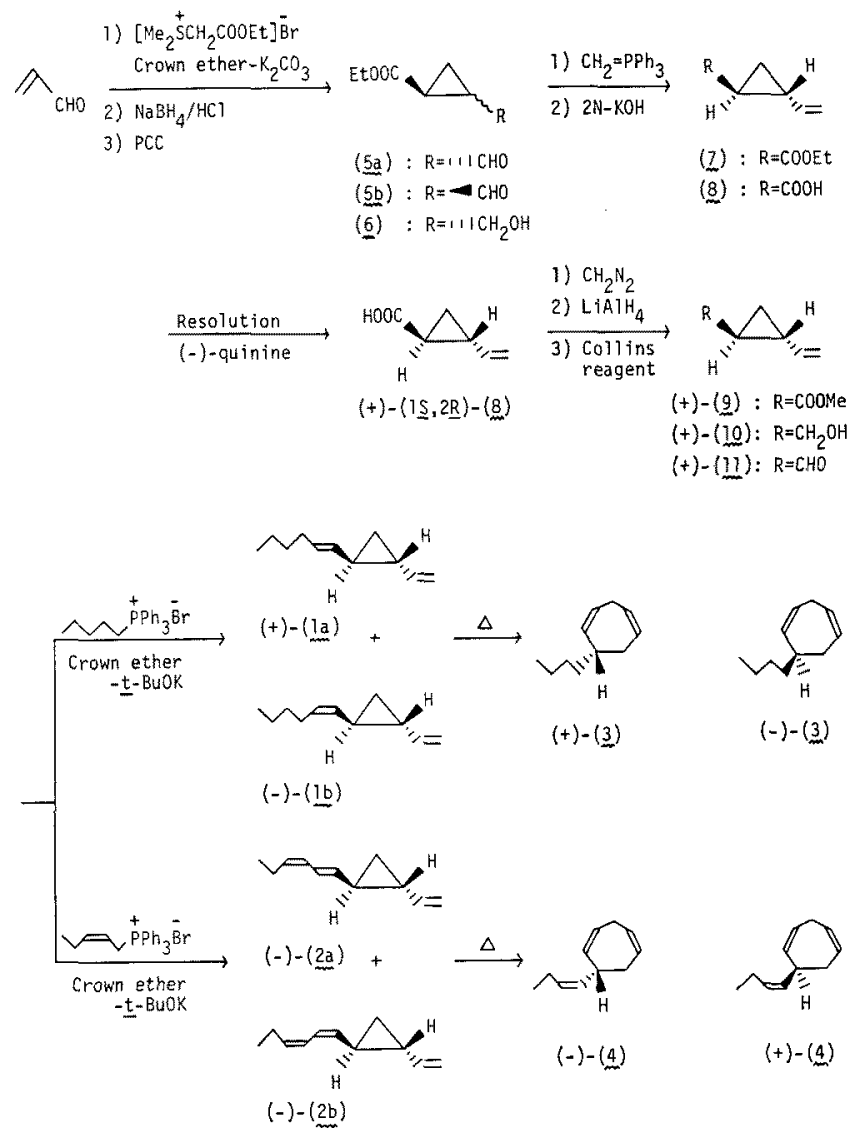

Fic. 1. Synthetic Route of Dictyopterenes A and B, and Their Geometrical Isomers.

Table I. Solvent Effect in the Formation OF ETHYL trans-2-FORMYLCYCLOPROPANECARBOXYLATE (5a) FROM ETHYL (DIMETHYLSULFURANYIIDENE) ACETATE AND ACROLEIN

\begin{tabular}{|c|c|c|c|}
\hline Solvent & $\begin{array}{l}\text { Dielectric } \\
\text { constant }(\varepsilon)^{a}\end{array}$ & trans/cis & $\begin{array}{l}\text { Yield } \\
(\%)^{b}\end{array}$ \\
\hline $\mathrm{CH}_{3} \mathrm{COCH}_{3}$ & 20.7 & $79 / 21$ & 43 \\
\hline $\mathrm{CH}_{2} \mathrm{Cl}_{2}$ & 8.93 & $77 / 23$ & 57 \\
\hline $\mathrm{C}_{8} \mathrm{H}_{5} \mathrm{OCH}_{3}$ & 8.80 & $90 / 10$ & 28 \\
\hline THF & 7.58 & $88 / 12$ & 18 \\
\hline $\mathrm{CHCl}_{3}$ & 4.80 & $76 / 24$ & 75 \\
\hline $\mathrm{C}_{2} \mathrm{H}_{5} \mathrm{OC}_{2} \mathrm{H}_{3}$ & 4.34 & $89 / 11$ & 44 \\
\hline $\mathrm{C}_{8} \mathrm{H}_{5} \mathrm{CH}_{3}$ & 2.38 & $87 / 13$ & 5 \\
\hline $\mathrm{CH}_{2} \mathrm{CH}_{2} \mathrm{O}$ & 2.21 & $90 / 10$ & 41 \\
\hline 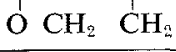 & & & \\
\hline
\end{tabular}

selectively the trans-isomer in satisfactory yields. This procedure promises to be a general method for syntheses of functionalized cyclopropanes from S-ylids and $\alpha, \beta$-unsatu- rated aldehydes.

The Wittig reaction between $\mathbf{5 a}$ and methylidenetriphenylphosphorane afforded ethyl 2vinylcyclopropanecarboxylate (7) $(90 \%)$. The ester (7) was hydrolyzed to 2-vinylcyclopropanecarboxylic acid (8). Resolution of the acid (8) with quinine gave $(+)-8 ;[\alpha]_{D}^{26}+178^{\circ}$. The absolute configuration of $(+)-\mathbf{8}$ was determined to be $1 S: 2 R^{*}$ since the Lemieux oxidation of this acid, $[\alpha]_{\mathrm{D}}^{26}+178^{\circ}$, gave $(+)-(R, R)$ trans-1,2-cyclopropanedicarboxylic acid which after Sephadex LH-20 column chromatography and recrystallization from acetonitrile had $\operatorname{mp} 175 \sim 177^{\circ}$ and $[\alpha]_{D}^{26}+201^{\circ}$ [reported to be $[\alpha]_{\mathrm{D}}^{22}+227.8^{\circ}(\mathrm{C}=2.342$, EtOH $), 96.3 \%$ optical purity]. ${ }^{15}$, The optical purity of $(+)-8,[\alpha]_{D}^{26}$ $+178^{\circ}$, was evaluated to be $85 \%$ from both

* The absolute configuration of (-)-8 except maximum rotation has been reported to be $(1 R, 2 S){ }^{17)}$ 
TABle II. Crown Ether and Solvent Effects IN THE Formation of 5a AND 1 b IN LIQUID-SOLID TWo-PHASE SYSTEMS

\begin{tabular}{|c|c|c|c|}
\hline Solvent & $\begin{array}{l}\text { Base and } \\
\text { Catalyst }\end{array}$ & $\begin{array}{c}\operatorname{trans}^{\prime} / \text { cis }^{\alpha} \\
(E) /(Z)\end{array}$ & $\begin{array}{c}\text { Yield } \\
(\%)\end{array}$ \\
\hline \multicolumn{2}{|c|}{ formation of cyclopropanes } & (trans/cis) & \\
\hline THF & $\begin{array}{l}\mathrm{K}_{2} \mathrm{CO}_{3} \\
18 \text {-crown-6 }\end{array}$ & $95 / 5$ & $58^{b}$ \\
\hline $\mathrm{THF}+\mathrm{CH}_{2} \mathrm{Cl}_{2} f$ & $\begin{array}{l}\mathrm{K}_{2} \mathrm{CO}_{3} \\
18 \text {-crown-6 }\end{array}$ & $88 / 12$ & $62^{\circ}$ \\
\hline $\mathrm{CH}_{2} \mathrm{Cl}_{2}$ & $\begin{array}{l}\mathrm{K}_{2} \mathrm{CO}_{3} \\
18 \text {-crown-6 }\end{array}$ & $87 / 13$ & $67^{\circ}$ \\
\hline $\mathrm{CH}_{2} \mathrm{Cl}_{2}$ & $\begin{array}{l}\mathrm{NaOH} \\
\text { 18-crown-6 }\end{array}$ & $81 / 19$ & $71^{c}$ \\
\hline \multicolumn{2}{|c|}{ formation of alkenes } & $(E / Z)$ & \\
\hline THF & $\begin{array}{l}t \text {-BuOK } \\
18 \text {-crown-6 }\end{array}$ & $5 / 95$ & $77^{d}$ \\
\hline $\mathrm{C}_{2} \mathrm{H}_{5} \mathrm{OC}_{2} \mathrm{H}_{5}$ & $\begin{array}{l}t \text {-BuOK } \\
18 \text {-crown-6 }\end{array}$ & $7 / 93$ & $70^{e}$ \\
\hline $\mathrm{CH}_{2} \mathrm{Cl}_{2}$ & $\begin{array}{l}t \text {-BuOK } \\
18 \text {-crown-6 } \\
t \text {-BuOK }\end{array}$ & $10 / 90$ & $80^{e}$ \\
\hline THF & $\begin{array}{l}\text { Dibenzo- } \\
\text { 18-crown-6 } \\
t \text {-BuOK }\end{array}$ & $6 / 94$ & $60^{e}$ \\
\hline $\mathrm{CH}_{2} \mathrm{Cl}_{2}$ & $\begin{array}{l}\text { Dibenzo- } \\
\text { 18-crown-6 }\end{array}$ & $9 / 91$ & $65^{e}$ \\
\hline
\end{tabular}

the rotation value of the derived dicarboxylic acid and the enantiomeric composition on GLC analysis of the diastereomeric esters of $(+)-8$ with $(-)-(R)$-2-octanol. Thus, the maximum rotation of $(+)-(1 S, 2 R)-8$ should be $[\alpha]_{D}^{26}+210^{\circ}$ in ethanol.

Esterification of $(+)-8$ with diazomethane and the subsequent reduction with $\mathrm{LiAlH}_{4}$, gave a hydroxy-cyclopropane, $[(+)-10](92 \%)$; $[\alpha]_{\mathrm{D}}^{26}+54^{\circ}$. This was oxidized with Collins reagent $^{16)}$ to an aldehyde $[(+)-11](88 \%)$, $[\alpha]_{D}^{26}+161^{\circ}$.

Preparation of dictyopterenes $[(+)-\mathbf{1 a}$ and (-)-2a] and their geometrical isomers [(-)$\mathbf{1 b}$ and (-)-2b]

i) Schlosser method. The Wittig reaction of $(+)$-11 with a pentylidenetriphenylphosphorane afforded a geometrical mixture of dictyopterene $\mathrm{A}[(+)$-1a] and the $(Z)$-isomer $[(-)-1 \mathrm{~b}](65 \%, E / Z=40 / 60)$ according to the method of Schlosser. ${ }^{18}$ The GLC separation of the mixture $[(+)-\mathbf{1 a}$ and $(-)-\mathbf{1 b}]$ allowed the isolation of $(+)-\mathbf{1 a},[\alpha]_{D}^{26}+65^{\circ}$, which was found to be identical with the natural $(+)$ dictyopterene A in $D$. prolifer $a^{19,201}$ and $D$. undulat $a^{20)}$ in all respects except the magnitude of optical rotation. The synthetic compound $(+)-1$ a had $87 \%$ optical purity on the basis of the reported $[\alpha]_{D}^{25}+72^{\circ} \quad(C=6.74$, $\left.\mathrm{CHCl}_{3}\right), 96.3 \%$ optical purity of naturally occurring dictyopterene A. ${ }^{3 \text { ) }}$

ii) Boden method. Boden et al. ${ }^{13)}$ reported a remarkable solvent effect on the Wittig reaction in the presence of crown ether. The ratio of $(Z)$ - and $(E)$-isomers in THF is $85: 15$, whereas in dichloromethane solution a reversal in product distribution is obtained for nonstabilized ylids. According to the method of Boden, ${ }^{13)}$ the Wittig reaction between the aldehyde $[(+)-11],[\alpha]_{0}^{26}+161^{\circ}$, and amyltriphenylphosphonium bromide in THF using crown ether- $t$-BuOK at $-10^{\circ} \mathrm{C}$, gave exclusively the geometrical $(Z)$-isomer $[(-)$-1b] of dictyopterene $\mathrm{A},(77 \%),[\alpha]_{\mathrm{D}}^{26}-123^{\circ}$. The geometrical purity of $(-)-\mathbf{1 b}$ was found to be $95 \%$ by GLC analysis. Solvent and crown ether effects in the reaction system of $(+)-11$ and the nonstabilized alkylidene phosphorane are summarized in Table $\mathrm{II} ;(Z) /(E)=95 / 5$ in THF and $(Z) /(E)=90 / 10$ in dichloromethane.

The Wittig reaction of the aldehyde $[(+)-11]$, $[\alpha]_{\mathrm{D}}^{2 \mathrm{~B}}+161^{\circ}$, with (Z)-2-pentenylidenetriphenylphosphorane in a mixed solvent of diethyl ether and THF, afforded a mixture of (-)-2a and $(-)-\mathbf{2} \mathbf{b}$, according to the method of Schlosser. ${ }^{18)}$ The mixture of $\mathbf{2 a}$ and $\mathbf{2} \mathbf{b}$ was partially rearranged to an enantiomer $[(-)-4]$ of the naturally occurring ectocarpene $[(+)-4]$ during GLC analysis. The retention times of the rearranged isomer $(-)-4$ and the synthetic compound (-)-2a were identical with those of natural dictyopterene B and ectocarpene, respectively, in the essential oils of $D$. prolifera $^{19,20)}$ and D. undulata. ${ }^{203}$

\section{EXPERIMENTAL}

IR spectra were taken with a Hitachi EPI-G2 spec- 
trometer using a potassium bromide disk. PMR spectra were obtained with a Varian Associate Model A-60 (60 MHz) spectrometer and a Hitachi PerkinElmer R-24 spectrometer in $d$-chloroform containing TMS as an internal reference. Mass spectra were obtained with a Shimadzu LKB-9000 GC-MS at $70.0 \mathrm{eV}$. Analytical and preparative GLC were performed on a Shimadzu GC-4B and a Varian Model 920 gas chromatograph, respectively. Optical rotations were determined with a JASCO DIP-SL automatic polarimeter.

Ethyl trans-2-formylcyclopropanecarboxylate (5a) ${ }^{12)}$ (modified method). ${ }^{13)}$ To a mixture of carboethoxymethyl dimethylsulfonium bromide $(2.4 \mathrm{~g}: 10 \mathrm{mmol})$, potassium carbonate (200 $\mathrm{mg}: 12 \mathrm{mmol}$ ) and 18crown-6 $(200 \mathrm{mg})$ in THF $(10 \mathrm{ml})$ was added acrolein (1 $\mathrm{ml}: 10 \mathrm{mmol}$ ) at room temperature. After stirring for $10 \mathrm{~min}$, the reaction mixture was filtered through silica gel (for dry column chromatography). Evaporation of the solvent gave ethyl 2-formylcyclopropanecarboxylates (5a and 5b) (800 mg: $58 \%$ ), 48 51 ${ }^{\circ} \mathrm{C}$ (0.5 $\mathrm{mmHg}$ ); trans/cis: $95 / 5$ by GLC analysis (19 $\mathrm{min}$ $5 \mathbf{a}$ and 28 min $5 \mathrm{~b}$; column $5 \%$ PEG $20 \mathrm{M}$ Shimalite W $3 \mathrm{~m} \times 3 \mathrm{~mm}$ at $120^{\circ} \mathrm{C}$, carrier gas $\mathrm{N}_{2} 40 \mathrm{ml} / \mathrm{min}$ ).

A solution of sodium borohydride $(0.5 \mathrm{~g}: 10 \mathrm{mmol})$ in methanol $(10 \mathrm{ml})$ was carefully added to the formylester [5a, $1 \mathrm{~g}: 7 \mathrm{mmol}$, containing 5\% cis-isomer (5b)] below $15^{\circ} \mathrm{C}$. The residue prepared in the usual way was distilled to give ethyl trans-2-hydroxymethylcyclopropanecarboxylate (6), bp $121 \sim 123^{\circ} \mathrm{C}(20 \mathrm{mmHg})$. The hydroxy-ester (6), without further purification, was subjected to PCC oxidation according to the method of Corey. ${ }^{14)}$ To pyridinium chlorochromate $(11.5 \mathrm{~g}$ : $50 \mathrm{mmol}$ ) in anhydrous dichloromethane $(72 \mathrm{ml})$ was added a solution of $6(5.0 \mathrm{~g}: 30 \mathrm{mmol})$ in dichloromethane $(7 \mathrm{ml})$. After stirring for $1.5 \mathrm{hr}$, the ethereal supernatant was decanted. The ether solution was passed through a short column $\left(\mathrm{SiO}_{2}\right.$ for dry column chromatography). The solvent was removed to give 5a $(3.2 \mathrm{~g}: 62 \%)$, bp $100 \sim 102 \mathrm{C} \quad(20 \mathrm{mmHg})$. IR $\nu_{\max }^{\text {film }} \mathrm{cm}^{-1}: 2820,1720 . \operatorname{PMR}\left(\mathrm{CDCl}_{3}\right) \delta: 1.3(3 \mathrm{H}, \mathrm{t})$, $4.2(2 \mathrm{H}, \mathrm{q}), 1.5 \sim 2.5(4 \mathrm{H}, \mathrm{m}), 9.2(1 \mathrm{H}, \mathrm{d}) . \quad 2,4-$ DNPH of $5 \mathrm{a}, \mathrm{mp} 108 \sim 109^{\circ} \mathrm{C}$. Found: C, 48.29; $\mathrm{H}, 4.38 ; \mathrm{N}, 17.11$. Calcd. for $\mathrm{C}_{13} \mathrm{H}_{14} \mathrm{O}_{8}: \mathrm{C}, 48.45$; $\mathrm{H}, 4.38 ; \mathrm{N}, 17.39 \%$.

trans-2-Vinylcyclopropanecarboxylic acid (8). ${ }^{17} \quad$ To a stirred solution of methyltriphenylphosphonium bromide (14.0 g: $39 \mathrm{mmol}$ ) in dry THF under a nitrogen atmosphere, was added $n$-butyllithium $(34.2 \mathrm{ml}: 60$ mmol) in $n$-hexane at $-40 \mathrm{C}$. A solution of $5 \mathrm{a}(4.2 \mathrm{~g}$ : $30 \mathrm{mmol}$ ) in THF was added to the resultant phosphorane at $-60^{\circ} \mathrm{C}$. After stirring for $5 \mathrm{hr}$ at room temperature, the reaction mixture was extracted with ether and dried over anhydrous sodium sulfate. The ether extract was concentrated and distilled to give $7(3.2 \mathrm{~g}$ :
$74.8 \%)$, bp $51 \sim 54^{\circ} \mathrm{C}(20 \mathrm{mmHg})$. The vinyl-ester $(7$, $4.9 \mathrm{~g}: 35 \mathrm{mmol}$ ) was refluxed with alcoholic $2 \mathrm{~N}$ potassium hydroxide $(25 \mathrm{ml})$ until the reaction mixture became transparent. After the solvent was removed in vacuo, the residue was extracted with ether. Evaporation of the solvent left a crude product which was distilled to give $\mathbf{8}(2.5 \mathrm{~g}: 71 \%)$, bp $88 \sim 90^{\circ} \mathrm{C}$ $(0.9 \mathrm{mmHg}) . \quad$ IR $\nu_{\max }^{\text {film }} \mathrm{cm}^{-1}: 3700 \sim 3000,1700$. PMR $\left(\mathrm{CDCl}_{3}\right) \delta: 0.8 \sim 2.3(4 \mathrm{H}, \mathrm{m}), 4.6 \sim 5.3(3 \mathrm{H}, \mathrm{m}), 10.9$ $(1 \mathrm{H}, \mathrm{s})$.

Optical resolution: $(+)-(1 S, 2 R)-2$-vinylcyclopropanecarboxylic acid $[(+)-8]$, The acid $[8,5.1 \mathrm{~g}: 45 \mathrm{mmol}]$ and (-)-quinine $(14.4 \mathrm{~g}: 45 \mathrm{mmol})$ were dissolved in hot ethanol $(13.5 \mathrm{ml})$. The solution was left to stand overnight and the solvent was evaporated in vacuo to give a crystal $(27.6 \mathrm{~g})$. The crystal was washed with ether $(200 \mathrm{ml})$ to afford cryst-1 $(22.1 \mathrm{~g}: \mathrm{mp} 87 \sim$ $\left.112^{\circ} \mathrm{C}\right)$, which became cryst-2 $\left(14.9 \mathrm{~g}: \mathrm{mp} 88 \sim 92^{\circ} \mathrm{C}\right)$ after crystallization from ethyl acetate. Further recrystallization of cryst-2 from ethyl acetate $(53 \mathrm{ml})$ provided cryst-3 $\left(8.9 \mathrm{~g}: \operatorname{mp} 83 \sim 87^{\circ} \mathrm{C}\right)$. Finally recrystallization of cryst-3 from a mixed solvent (AcOEt $36 \mathrm{ml}$ and $\mathrm{Et}_{2} \mathrm{O} 47 \mathrm{ml}$ ) afforded cryst $4(3.7 \mathrm{~g}: \mathrm{mp}$ $134 \sim 144^{\circ} \mathrm{C}$ ) and a filtrate. The filtrate was concentrated to give cryst-5 (mp $114 \sim 115^{\circ} \mathrm{C}$ ). Cryst-4 was decomposed with $2 \mathrm{~N}$ hydrochloric acid in ether and the ether solution was dried over anhydrous sodium sulfate. The solvent was evaporated to give $(+)-8$, $(840 \mathrm{mg}),[\alpha]_{\mathrm{D}}^{26}+178^{\circ}(C=1.1$, EtOH $)$. On the other hand, the decomposition of cryst-5 afforded (-)-8, $[\alpha]_{\mathrm{D}}^{28}-160^{\circ}(C=1.0, \mathrm{EtOH})$.

(+)-(lS, 2R)-Methyl 2-vinylcyclopropanecarboxylate $[(+)-9]$. To an ether solution of the acid $[(+)-8$; $\left.1.2 \mathrm{~g}: 11 \mathrm{mmol},[\alpha]_{\mathrm{D}}^{26}+178^{\circ}\right]$ was added diazomethane in ether. The solvent was removed and the residue was distilled to give $(+)-9(1.1 \mathrm{~g}: 80 \%)$, bp $51 \sim 53^{\circ} \mathrm{C}$ $(120 \mathrm{mmHg}),[\alpha]_{\mathrm{D}}^{26}+191^{\circ}(c=1.1$, EtOH $)$. IR $\nu_{\max }^{\text {film }}$ $\mathrm{cm}^{-1}: 1720,1640$. PMR $\left(\mathrm{CDCl}_{3}\right) \delta: 0.9 \sim 2.2(4 \mathrm{H}, \mathrm{m})$, $4.1(3 \mathrm{H}, \mathrm{s}), 4.5 \sim 5.3(3 \mathrm{H}, \mathrm{m})$.

$(+)-(1 S, 2 R)-2-V i n y l c y c l o p r o p y l c a r b i n o l \quad[(+)-10]$. The reduction of $(+)-9\left(1.2 \mathrm{~g}: 9 \mathrm{mmol},[\alpha]_{D}^{26}+191^{\circ}\right)$ with lithium aluminum hydride $(0.45 \mathrm{~g}: 10 \mathrm{mmol})$ gave $(+)-10(820 \mathrm{mg}: 89 \%)$ bp $86 \sim 89^{\circ} \mathrm{C}(90 \mathrm{mmHg}),[\alpha]_{\mathrm{D}}^{26}$ $+54^{\circ}(C=1.0$, EtOH $)$. IR $\nu_{\max }^{\text {film }} \mathrm{cm}^{-1}: 3300,1620$. $\operatorname{PMR}\left(\mathrm{CDCl}_{3}\right) \delta: 0.4 \sim 1.5(4 \mathrm{H}, \mathrm{m}), 3.4(2 \mathrm{H}, \mathrm{m}), 4.5 \sim$ $5.6(3 \mathrm{H}, \mathrm{m})$.

(+)-(1S,2R)-2-Vinylcyclopropylcarbaldehyde [(+)-11]. The oxidation of $(+)-10\left(1.1 \mathrm{~g}: 11 \mathrm{mmol},[\alpha]_{\mathrm{D}}^{26}+54^{\circ}\right)$ according to the method of Collins ${ }^{16)}$ gave $(+)-11$ (808 mg: $81 \%$ ), bp $43 \sim 45^{\circ} \mathrm{C}(15 \mathrm{mmHg}),[\alpha]_{D}^{n 6}+161^{\circ}$ $\left(C=0.86\right.$, THF). IR $\nu_{\max }^{\text {film }} \mathrm{cm}^{-1}: 2850,2750,1720$. PMR $\left(\mathrm{CDCl}_{3}\right) \delta: 0.5 \sim 2.5(4 \mathrm{H}, \mathrm{m}), 4.8 \sim 5.5(3 \mathrm{H}, \mathrm{m})$, 
9.2 (1H, d). 2,4-DNPH of $(+)-11, \mathrm{mp} 152 \sim 154^{\circ} \mathrm{C}$. Found: $\mathrm{C}, 52.33 ; \mathrm{H}, 4.12 ; \mathrm{N}, 20.55$. Calcd. for $\mathrm{C}_{12} \mathrm{H}_{12} \mathrm{O}_{4} \mathrm{~N}_{4}: \mathrm{C}, 52.37 ; \mathrm{H}, 4.38 ; \mathrm{N}, 20.55 \%$.

\section{(+)-Dictyopterene $A[(+)-1 \mathrm{a}]$ and its geometrical isomer [(-)-1b]}

i) Schlosser method. ${ }^{18)}$ The Wittig reaction between $(+)-11\left(400 \mathrm{mg}: 5 \mathrm{mmol},[\alpha]_{\mathrm{D}}^{26}+161^{\circ}\right)$ and pentylidenetriphenylphosphorane in a mixed solvent of ether $(7 \mathrm{ml})$ and THF $(7 \mathrm{ml})$ gave a mixture of dictyopterenes [(+)-1a and (-)-1b] $(420 \mathrm{mg}: 72 \%)$. The ratio of $(+)-1 a$ and (-)-1b was found to be $40 / 60$ by GLC analysis.

The separation of the geometrical isomers $[(+)-\mathbf{1 a}$ and (-)-1b] was performed by preparative GLC [23.0 $\mathrm{min}(+)-1 \mathrm{a}$ and $20.0 \mathrm{~min}(-)-1 \mathrm{~b}$; column $15 \%$ DEGS Chromosorb WAW $3 \mathrm{~m} \times 4 \mathrm{~mm}$ at $70^{\circ} \mathrm{C}$, carrier gas $\mathrm{He} 30 \mathrm{ml} / \mathrm{min}]$. Optical rotation of the separated compound $(+)-1 \mathrm{a}$ was $[\alpha]_{0}^{26}+65^{\circ}\left(C=0.3, \mathrm{CHCl}_{3}\right)$, $87 \%$ optical purity based on the reported $[\alpha]_{\mathrm{D}}^{25}+72^{\circ}$ $\left(C=6.74, \mathrm{CHCl}_{3}\right), 96.3 \%$ optical purity. ${ }^{32} \quad$ IR $\nu_{\max }^{\mathrm{film}}$ $\mathrm{cm}^{-1}: 3080,3000,1665,1635,980,958(E,-\mathrm{CH}=\mathrm{CH}-)$, 892. PMR $\left(\mathrm{CDCl}_{3}\right) \delta: 0.5 \sim 1.1(5 \mathrm{H}), 1.1 \sim 1.9(6 \mathrm{H})$, $2.0(2 \mathrm{H}, \mathrm{q}, J=7), 4.5 \sim 5.8(5 \mathrm{H}) .^{3,5,8)}$ MS m/e: 150 $\left(\mathrm{M}^{+}, 5 \%\right), 79(100) .{ }^{3,5,8)}$ The retention time of the synthetic isomer $(+)-1 a$ was identical with that of natural dictyopterene $A$ in the essential oils of $D$. prolifera $^{19,20)}$ and $D$. undulata ${ }^{20)}(8.1 \mathrm{~min}$ dictyopterene $\mathrm{A}$ and $7.0 \mathrm{~min}(-)-1 \mathrm{~b}$; column 5\% PEG $20 \mathrm{M}$ Shimalite W $3 \mathrm{~m} \times 3 \mathrm{~mm}$ at $90^{\circ} \mathrm{C}$; injector temp., $120^{\circ} \mathrm{C}$; flow rate $\mathrm{N}_{2} 60 \mathrm{ml} / \mathrm{min}$ ). On the other hand, the value of the isolated compound $(-)-1 b$ was $[\alpha]_{D}^{26}-123^{\circ}(C=$ $0.77, \mathrm{CHCl}_{3}$ ). IR $2_{\max }^{\mathrm{film}} \mathrm{cm}^{-1}: 3080,3025,3000$, $2965,2935,2875,1630,1600,1450,1205,990,900,725$ $(Z,-\mathrm{CH}=\mathrm{CH}-) . \quad \operatorname{PMR}\left(\mathrm{CDCl}_{3}\right) \delta: 0.5 \sim 1.1 \quad(5 \mathrm{H})$, $\left.1.1 \sim 1.9(6 \mathrm{H}), 2.16(2 \mathrm{H}, \mathrm{q}, J=7), 4.5 \sim 5.8(5 \mathrm{H}) .{ }^{5}, 8\right)$ ${ }^{13} \mathrm{C}-\mathrm{NMR}\left(\mathrm{CDCl}_{3}\right) \delta: 14.0\left(\mathrm{CH}_{3}\right), 15.5\left(\mathrm{CH}_{2}\right), 19.8(\mathrm{CH})$, $22.3\left(\mathrm{CH}_{2}\right), 24.5(\mathrm{CH}), 27.4\left(\mathrm{CH}_{2}\right), 32.0\left(\mathrm{CH}_{2}\right), 112.0$ $\left(\mathrm{CH}_{2}\right), 129.4(\mathrm{CH}), 131.9(\mathrm{CH}), 140.8(\mathrm{CH}), \quad \mathrm{MS} m / e$ : $150\left(\mathrm{M}^{+}, 13 \%\right), 135(1), 121(7), 109(10), 107(16)$, $94(21), 93(46), 91(43), 80(58), 79(100), 78(38)$, $77(44), 67(54), 66(45), 55(35), 41(74), 39(54), 29$ (36), 27 (44).

ii) Boden method. ${ }^{13)}$ To a mixture of amyltriphenylphosphonium bromide (254 mg: $0.52 \mathrm{mmol}$ ), (+)-11 (50 mg: $\left.0.5 \mathrm{mmol},[\alpha]_{\mathrm{D}}^{26}+161^{\circ}\right)$ and 18 -crown-6 in THF ( $3 \mathrm{ml}$ ) was added potassium $t$-butoxide $(200 \mathrm{mg}$ : $0.5 \mathrm{mmol}$ ) at $-10^{\circ} \mathrm{C}$. The reaction mixture was passed through a dry column $\left(\mathrm{SiO}_{2}\right)$ using ether. The solvent was removed to give $(-)-1 \mathrm{~b}(56 \mathrm{mg}: 77 \%$ ), geometrical purity $95 \%$ on GLC analysis.

(-)-Dictyopterene $B[(-)-2 \mathrm{a}]$ and its geometrical isomer $[(-)-2 \mathbf{b}]$. After $n$-butyllithium was introduced to a stirred solution of $(Z)$-2-pentenyltriphenylphosphonium bromide ( $25 \mathrm{mg}: 0.6 \mathrm{mmol}$ ) in THF at $-40^{\circ} \mathrm{C}$, $(+)-11\left(50 \mathrm{mg}: 0.5 \mathrm{mmol},[\alpha]_{\mathrm{D}}^{26}+161^{\circ}\right)$ was added and the reaction mixture was passed through a dry column $\left(\mathrm{SiO}_{2}\right)$ with petroleum ether. The eluate was concentrated to give a mixture of dictyopterenes $[(-)-2 \mathbf{a}$ and (-)-2b] (54 mg: 72.8\%). The mixture of (-)-2a $(36.8 \mathrm{~min})$ and (-)-2b (33.0 min) was partially rearranged to (-)-4 (24.0 $\mathrm{min})$ during GLC separation (column 15\% Silicone DC QF-1 Chromosorb WAWDMCS $3 \mathrm{~m} \times 4 \mathrm{~mm}$ at $80^{\circ} \mathrm{C}$, carrier gas $\mathrm{He} 50 \mathrm{ml} /$ min). (-)-2a; $[\alpha]_{D}^{26}-37^{\circ}\left(C=0.3, \mathrm{CHCl}_{3}\right)$; IR $\nu_{\max }^{\mathrm{film}}$ $\mathrm{cm}^{-1}:$ 3080, 1630, 1210, 990, 953, 725. PMR $\left(\mathrm{CDCl}_{3}\right)$ $\delta: 0.5 \sim 1.8(7 \mathrm{H}), 2.0$ (quintet, $2 \mathrm{H}, J=7.0$ ), $4.7 \sim 6.9$ $(7 \mathrm{H}){ }^{3)} \quad \mathrm{MS} m / e: 148\left(\mathrm{M}^{+}, 12 \%\right), 79(100) . \quad(-)-2 \mathrm{~b}$; $[\alpha]_{\mathrm{D}}^{26}-78^{\circ}\left(C=1.2, \mathrm{CHCl}_{3}\right) ; \mathrm{IR} \nu_{\max }^{\operatorname{tilm}} \mathrm{cm}^{-1}: 3080,3250$, $3000,2950,2935,2875,1630,1600,1450,1205,990$, 900, $725(Z-,-\mathrm{CH}=\mathrm{CH}-) . \quad \operatorname{PMR}\left(\mathrm{CDCl}_{3}\right) \delta: 0.5 \sim 1.8$ (7H), 2.2 (quintet, $2 \mathrm{H}, J=7.0$ ), $4.7 \sim 6.9(7 \mathrm{H}) . \quad$ MS $m / e: 148\left(\mathrm{M}^{+}, 18 \%\right), 133(5), 119(29), 117(7), 115$ $(5), 105(36), 91(90), 79(100), 77(32), 67(28), 66(42)$, $65(14), 55(6), 41(62), 29(14), 27$ (24).

The retention times of the synthetic compound $(-)-\mathbf{2 a}$ and the rearranged isomer $(-)-4\left[[\alpha]_{D}^{96}-11^{\circ}(C=0.9\right.$, $\left.\mathrm{CHCl}_{3}\right)$ ] coincided with those of the natural dictyopterene $\mathrm{B}$ and ectocarpene, respectively (17.4 min dictyopterene B, $16.2 \mathrm{~min}(-)-2 \mathrm{~b}, 12.4 \mathrm{~min}$ ectocarpene; column $5 \%$ PEG $20 \mathrm{M}$ Shimalite $\mathrm{W} 3 \mathrm{~m} \times 3 \mathrm{~mm}$ at $90^{\circ} \mathrm{C}$; injector temp., $120^{\circ} \mathrm{C}$; flow rate $\mathrm{N}_{2} 60 \mathrm{ml} / \mathrm{min}$ ).

Optical purity and absolute configuration of (+)-2vinylcyclopropanecarboxylic acid $[(+)-8]$

i) GLC analysis. To a mixture of $(+)-8[200 \mathrm{mg}$ $\left.(1.8 \mathrm{mmol}),[\alpha]_{\mathrm{D}}^{26}+178^{\circ}\right]$ and dry benzene $(1.5 \mathrm{ml})$ was added oxalyl chloride (226 $\mathrm{mg}: 1.8 \mathrm{mmol}$ ) at room temperature. After the reaction mixture was warmed to $35^{\circ} \mathrm{C}$ and stirred for $20 \mathrm{~min}$, the solvent was removed to give the acyl chloride (192 $\mathrm{mg}: 89 \%$ ). IR $\nu_{\max }^{\mathrm{fllm}}$ $\mathrm{cm}^{-1}: 1640,1800,740$. The acyl chloride $(47 \mathrm{mg}$ : $0.3 \mathrm{mmol})$ in dry benzene $(6 \mathrm{ml})$ was added at room temperature to a stirred solution of $(-)-(R)$-2-octanol (32 $\mathrm{mg}: 0.3 \mathrm{mmol})$ in benzene $(6 \mathrm{ml})$. After stirring for $1 \mathrm{hr}$, the reaction mixture was refluxed for $2 \mathrm{hr}$ and was concentrated in vacuo to a volume of approximately $1 \mathrm{ml}$. This product was purified by column chromatography on $\mathrm{Al}_{2} \mathrm{O}_{3}$ using benzene. Evaporation of benzene gave diastereomeric esters ( $54 \mathrm{mg}$ : $64 \%$ ). IR $\nu_{\max }^{\mathrm{film}} \mathrm{cm}^{-1}: 2960,1700$. The diastereomers were subjected to GLC analysis $(32.7 \mathrm{~min} l$-isomer, $33.7 \mathrm{~min}$ $d$-isomer; capillary column PEG $20 \mathrm{M}$ (containing $\left.\mathrm{BaCO}_{3}\right) 28 \mathrm{~m}$ at $70 \sim 180^{\circ} \mathrm{C}\left(2^{\circ} \mathrm{C} / \mathrm{min}\right)$. The optical purity of $(+)-8\left([\alpha]_{\mathrm{D}}^{26}+178^{\circ}\right)$ was determined to be $85 \%$ and the maximum rotation should be $[\alpha]_{\mathrm{D}}^{26}+210^{\circ}$ in ethanol.

ii) Lemieux oxidation. ${ }^{21}$ According to the method of Moore, ${ }^{8)}(+)-8\left(365 \mathrm{mg},[\alpha]_{\mathrm{D}}^{26}+178^{\circ}\right)$ was oxidized to give $220 \mathrm{mg}$ of solid which was dissolved in $1 \mathrm{ml}$ of 
$50 \% \mathrm{CHCl}_{3}-\mathrm{MeOH}$ and applied to a $1.7 \times 60 \mathrm{~cm}$ column of Sephadex LH-20. Evaporation of the solvent of the eluate (fractions $25 \sim 28$, each $5 \mathrm{ml}$ ) gave $(R, R)$-trans-cyclopropane-1,2-dicarboxylic acid (mp $175 \sim 177^{\circ} \mathrm{C}$ from acetonitrile, $[\alpha]_{D}^{26}+201^{\circ}$ ) which is $85 \%$ optical purity based on the reported $[\alpha]_{\mathrm{D}}^{26}+227.8^{\circ}$ $\left(C=2.342\right.$, EtOH), $96.3 \%$ optical purity. ${ }^{15)}$ Thus, the configuration of $(+)-8$ was determined to be $1 S: 2 R$.

Acknowledgments. This work was supported in part by grants from the Mishima Kaiun Foundation of Japan and the Agricultural Chemistry Foundation of Japan. We wish to express our thanks to Professors $\mathrm{Y}$. Inouye and $\mathrm{J}$. Oda, Institute for Chemical Research, Kyoto University, for helpful discussion and elemental analyses and Mr. Kido for his skilled technical assistance. Our thanks are also due to Drs. E. Nakai, $\mathrm{T}$. Ohshima and T. Honda, Ube Industry of ${ }^{18} \mathrm{C}-\mathrm{NMR}$ and optical rotation measurements.

\section{REFERENCES}

1) R. E. Moore, J. A. Pettus, Jr., and M. S. Doty, Tetrahedron Lett., 4787 (1968).

2) J. A. Pettus, Jr., and R. E. Moore, Chem. Commun., 1093 (1970).

3) R. E. Moore, J. A. Pettus, Jr., and J. Mistysyn, J. Org. Chem., 39, 2201 (1974).

4) D. G. Müller, L. Jaenicke, M. Donike and T. Akintobi, Science, 171, 815 (1971).
5) G. Ohloff and W. Pickenhagen, Helv. Chim. Acta., 52, 880 (1969).

6) K. C. Das and B. Weinstein, Tetrahedron Lett., 3459 (1969).

7) A. W. Burgstahler and C. M. Groginsky, Trans. Kans. Acad. Sci., 72, 486 (1970).

8) T. Kajiwara, M. Ohno and Y. Inouye, Bull. Inst. Chem. Res., Kyoto University, 49, 179 (1971).

9) L. Jaenicke, T. Akintobi and F. J. Marner, Liebigs Ann. Chem., 8, 1252 (1973).

10) W. E. Billups, W. Y. Chow and J. H. Cross, Chem. Commun, 252 (1974).

11) A. Ali, D. Sarantakis and B. Weinstein, ibid., 940 (1971).

12) G. B. Payne, J. Org. Chem., 32, 3351 (1967).

13) R. M. Boden, Synthesis, 748 (1975).

14) E. J. Corey and J. W. Suggs, Tetrahedron Lett., 2647 (1975).

15) Y. Inouye, T. Sugita, and H. M. Walborsky, Tetrahedron, 20, 1695 (1964).

16) J. C. Collins, W. W. Hess and F. J. Frank, Tetrahedron Lett., 3363 (1968).

17) M. Arai and R. J. Crawford, Can. J. Chem., 50, 2158 (1972).

18) M. Schlosser, G. Müller and K. F. Christmann, Angew. Chem. Internat. Edit., 5, 126 (1966).

19) K. Yamada, H. Tan and H. Tatematsu, Chem. Commun., 572 (1979).

20) T. Kajiwara, K. Kodama and A. Hatanaka, Bull. Japan. Soc. Sci. Fish., 46, 771 (1980).

21) E. von Rudloff, Can. J. Chem., 43, 2660 (1965). 